\title{
Reconstruction Material Sumping Accesories with Customization Design \\ (Joni Permana Artwork)
}

\author{
Rika Nugraha \\ e-mail: rika.nugraha@uniku.ac.id \\ Elin Herlina \\ e-mail: erlin.herlina@uniku.ac.id \\ Visual Communication Design Department \\ Computer Sciences Faculty- Kuningan University \\ e-mail: rika.nugraha@uniku.ac.id
}

\begin{abstract}
Abstrak
Sumping adalah sejenis perhiasan yang dikenakan pada telinga. Sumping biasanya berupa ukiran yang ditatah dengan bentuk menyerupai sayap burung atau sulur helai daun. Cara mengenakan sumping adalah menyelipkan daun telinga pada lubang melengkung yang terdapat pada sumping. Sumping ditemukan dalam khazanah Indonesia, khususnya budaya Jawa dan juga pada busana tradisional Thailand, dikenakan sebagai atribut busana penari. Sumping merupakan salah satu atribut kelengkapan busana tarian Jawa seperti tari serimpi dan wayang orang. Karya seni berupa Sumping telah di rekonstruksi oleh Joni Permana sebagai designer costum art, Sumping yang kini tidak lagi digunakan pada pelengkap tari tradisional, melalui costumized design tampilan Sumping memiliki point of interest dalam setiap penampilannya.Rekonstruksi dilakukan dengan tidak mengubah bentuk sumping serta kegunaannya, namun upaya rekonstruksi dilakukan agar penggunaan sumping tetap terpelihara melalui budaya inovasi.Sumping memiliki nilai budaya tinggi sebagai produk budaya serta mempunyai nilai estetik dalam setiap karyanya sehingga warisan budaya tetap memiliki eksistensi secara berkesinambungan.
\end{abstract}

Kata Kunci-Rekonstruksi, Sumping, Kustomisasi

\begin{abstract}
Sumping is a type of jewelry worn on the ears. It is usually carved in the shape resemble with wings of a bird or swirls strands of leaves. Way of wearing sumping is tucking the earlobe on the curved hole sumping. It is found in Indonesia, especifically in Javanese culture and traditional dress, worn as attributes on Thailand clothing dancers. Sumping is one of the attributes of the completeness of the clothing dance like Java serimpi dance and puppet people. Works of art in the form of Sumping has been reconstructed by Joni Permana as costum art designer, Sumping which is now no longer used as the complement of traditional dance, through display design costumized Sumping has a point of interest in any performance. The reconstruction is done by not changing the form as well as its usefulness, but sumping effort of reconstruction is done so that the use of sumping maintained through a culture of innovation. Sumping has high cultural value as cultural products as well as aesthetic value in its works so that cultural heritage still has continuous existence.
\end{abstract}

Keywords- . Reconstruction, Sumping, Customization 


\section{INTRODUCTION}

Sumping, a work culture, is created through a system that has the coherence. The symbolic form of words, things, mannerisms, mite, literature, painting, singing, music, the trust that have a relation with the epistemological concept of community knowledge systems. Material culture in the form of buildings, equipment and weaponry cannot be released from the entire configuration of the culture.

Clothing, costumes and make-up are forms of communication hypercontraction (artifactual communication) which is defined as direct communication through the arrangement of artifacts such as clothes, make-up, jewellery, clothes or studs.

In the consumer culture, the body is expressed as a mean of enjoyment ( $a$ vehicle of pleasure). As a form of enjoyment, adornment conveys hypercontraction message as nonverbal message. Jewelry is an individualistic expression that is used to distinguish itselves as individual and States form of its uniqueness. Sumping as cultural artefactual is created by means that are used for different types and combined to produce a meaning discussion of bricolage ${ }^{1}$.

The artifact is the cultural production in the era of mass cultural products manufactured objects (produced) so that it can occur between the criterion of high art and low art in manufacturing process that treats consumers as its object.

As for material reconstruction, sumping has aesthetic value sustainability as an effort to improve the quality of visual culture. More specification can be understood as an increase in understanding material reconstruction skills and absorbing everything that supports an increased appreciation of the aesthetic value in deciding draft choices to be produced.

\section{RESEARCH METHODS}

As sumping, as a product of culture produced by Joni Permana, this material so that reconstruction is a method used to find out the conclusion then it is used as comparative method between old sumping and sumping materials produced by Joni Permana

\subsection{Theory of Comparative}

Making comparisons between products, designer, style is one of the routine activities of designing history and critics and even the comparative method and it's less critical attention. Objectivity compares and diferenciates various types to uncover a range of similarities and differences. In other words, the comparative method can work better when two types of products have some same characteristics but they have varieties in terms of other.

Comparing means represents the first stage followed by a historical reconstruction. A person can be authoritative identifying various motif and comprehend the blessed transformation by tracing the various motives of those back in the original form and recognizing the original purpose, material and techniques ${ }^{2}$.

Ferdinand de Saussure, the originator of modern Linguistics adds comparisons need to be made for the reconstruction of any history, but on his own statement, he could not produce a conclusion. The only way is reconstructing by comparing its reconstruction purposes.

\footnotetext{
${ }^{1}$ bricolage, wearing a weird stuff and aims to create a new and original

${ }^{2}$ Walker, John.1989. Desain, Sejarah dan

Budaya. Jalasutra.
} 


\subsection{Theory of Customization}

It is used to be a craft manufacturing era and the product is very limited. Each item produced has limited variation (low variety) and high prices (high price) even every production needs quite a long time. With the advance of the industrial revolution, the emergence of machinery manufacturing production moved from the era of the craft to an era of mass production (Mass Production) making kinds of limited products (low variety) with cheap prices (low price) as well as the production time faster.

At this time there is a new era which appears in the form of mass Customization (Mass Customization). According to Laudon (2010) mass customization is the ability to offer products or services that are customised individually by using the same production resources such as mass production.

Mass Customization makes the product more markedly (High Variety) with cheap price (Low Price). Mass Customization can customize products rapidly for customers as well as for individual market (niche) product efficiency of mass production and the time of production is faster. Using the same principle of mass customization is a Build-to-order, customized products but it may also be mass-produced.

According to Gilmor and Joseph (1997) there are 4 approaches in customization ${ }^{3}$ are:

\section{Collaborative Customizers}

The approach to the customer where the customer or individual conducts the dialogue to help articulating their needs and to make products that are tailored to them.

Example: Hair Salon, customers can consult or dialogue about the kind/type of desired hair.

\section{Adaptive Customer}

Manufactur offers standard products, but they can still be adjusted. The product is designed in the form of the standard made in such a way that the user can still change it yourself.

Example: Mobile, by immersing the technology inside, every customer can add functionality in that product.

\section{Cosmetic Customer}

It presents the different standard products for different customers. Cosmetic approach is just when customers use the product the same way and only differ in how they wish to be served. It offers a standard packaged specifically for each customer.

Example: Sugar packed in packing $1 / 2 \mathrm{~kg}, 1$ $\mathrm{kg}, 2 \mathrm{~kg}$, so that customers have the option.

\section{Transparant Customizer}

It provides customers with a unique service product without letting them to know explicitly that the products and services have been tailored for them. The transparent approach is for customizations right when the specific needs of customers can be predicted easily or it can be summed up and especially when customers state their needs repeatedly.

Example: cars, with different colors based on the desire of many individuals are followed by many manufactures.

\footnotetext{
3 The FourFaces Of Mass Customization. Harvard Business Review; Vol 5 Issue 1 Page 91-101 Jan/ Feb 1997. United States
} 


\subsection{RESULTS AND DISCUSSION}

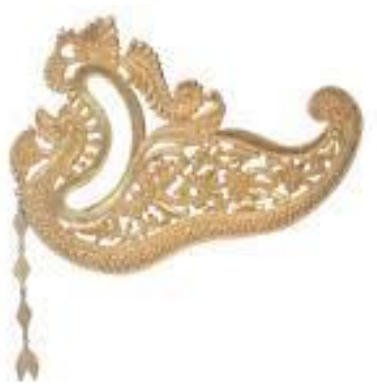

Figure 1. Ricikan Sumping (Puppet accesories) Material from mixture of zinc (Source:

\section{http://sekarbudayanusantara.co.id)}

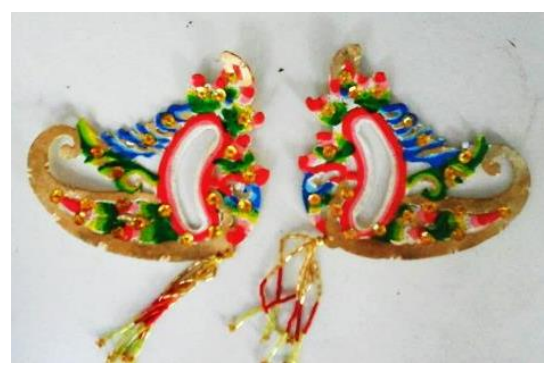

Figure 2. Kuda Lumping Sumping Material from mixture of leather and beads (Source : Jatiarum, 2017)

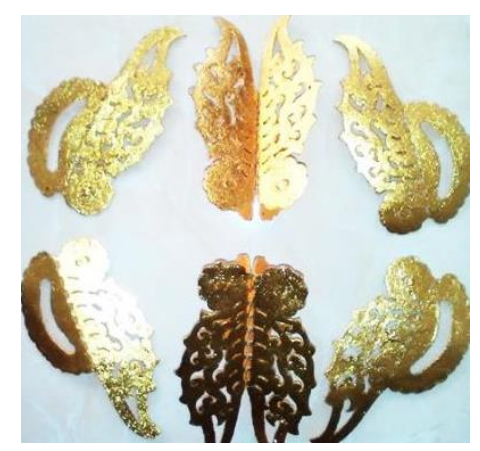

Figure 3. Traditional Sumping Material from mixture of leather and gold paint

(Source : Anom Tri Setiawan, 2017)

The use of sumping is worn as fashion for completeness in a traditional dance of the equation i.e. using materials are lightweight, made of sheepskin and have a finishing with a variety of colors. The dominant color used such as gold color as a neutral color. As for the addition of customized beads sumping needs such as colored on the mask dance.

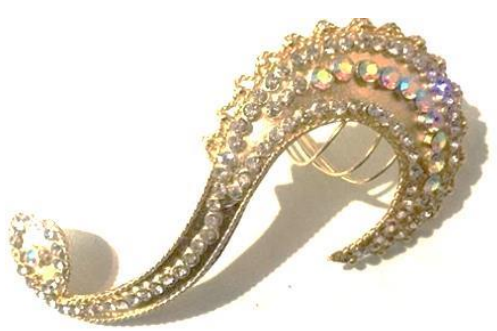

Figure 4. Yogyakarta dance supplies Material from mixture of copper and gems (Source : Bambanglipuro, 2017)

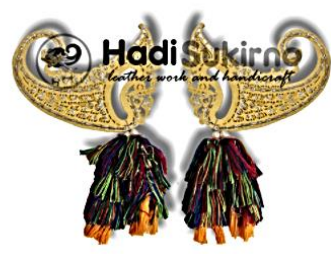

Figure 5. Yogyakarta Sumping Material From Leather and Yarn (Source: Sukirno, Hadi, 2018)

\section{CONCLUSION}

Widely used as traditional Sumping completeness of dance fashion in its activity is required in dancers performance so it is made using sumping leather material. Audience performances geared intact to see a show not on accesoris, but dance to the rhythm of motion.

The art of dance or performance is a nonverbal communication media that in the show it made interesting based on consideration of the artistic and aesthetic grounds.In the context of cultural, aesthetic value on the work of the design can be understood as an effort to build awareness against ' something '. Side of awareness that can occur through increased appreciation of cultural objects in everyday life, nor the 
implementation of aesthetic values in a number of design works.Sumping as traditional objects of culture that has aesthetic value of historical awareness is going to be applicable to the art community. Reconstruction through our material aims to support the awareness of historic value that is implemented in the form of immediacy.

The reconstruction effort is a tradition of innovation for improving visual quality and remaining aligned with their needs and developed into an innovation culture.The customization process of Sumping material emphasizing on aesthetic appeal. The appeal of this aesthetic can emerge from the aspect of forms (formal), content (symbol) and the expression of emotions (expression). It results formalism, symbolism and expressionism analysis model. Formal analysis of art works are considering as aesthetic effect first created by parts of the formal components of art and design. This section is called form elements (formal element): line, raut (shape), texture, space, color and light. It is arranged in a variety of different ways to generate a composition of art or design products.

Reconstruction through material aims to support the awareness of historic value that is implemented in the form of immediacy. The reconstruction effort is a tradition of innovation for improving visual quality and remain aligned with their needs and developed into an innovation culture. The process of customization of material use, sumping emphasises on aesthetic appeal. The appeal of this aesthetic can emerge from the aspect of forms (formal) content (symbol) and the expression of emotions (expression). It results formalism, symbolism and expressionism analysis model. Formal analysis of art works is considering aesthetic effect first created by parts of the formal components of art and design. This section is called the form elements (formal element): line, (shape), texture, space, color and light, arranged in a variety of different ways to generate a composition of art or design products.

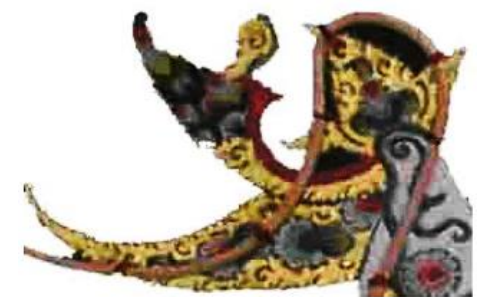

Figure 6. Pudak Sinumpet Sumping (2 Dimensions) Material From Leather

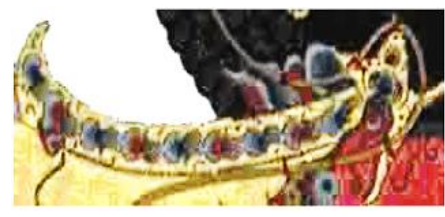

Figure 7. Sekar Kluwih Sumping (2 Dimensions) Material From Leather

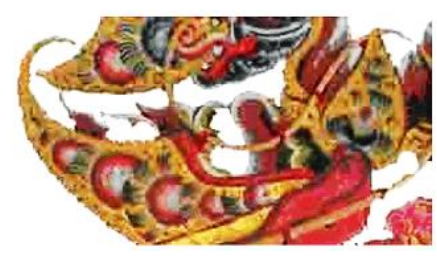

Figure 8. Surengpati Sumping (2 Dimensions) Material From Leather

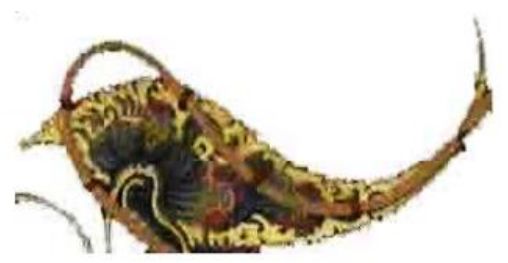

Figure 9. Waderan Sumping

(2 Dimensions)

Material From Leather

The four types of Sumping above have the appearance of 2-dimensions and they have different elements with the display that has 3 dimensional sumping. It can be seen in the following table: 


\begin{tabular}{|c|c|c|c|c|}
\hline $\begin{array}{l}\mathrm{N} \\
\mathrm{O}\end{array}$ & Name & $2 \mathrm{D}$ & $\begin{array}{l}3 \\
\mathrm{D}\end{array}$ & Material \\
\hline 1 & $\begin{array}{l}\text { Sumping Pudak } \\
\text { Sinumpet }\end{array}$ & & & $\begin{array}{c}\text { Leather } \\
\text { Black Paint } \\
\text { Gold Paint } \\
\text { Red Paint } \\
\text { Grey Paint }\end{array}$ \\
\hline 2 & $\begin{array}{l}\text { Sumping Sekar } \\
\text { Kluwih }\end{array}$ & & & $\begin{array}{l}\text { Leather } \\
\text { Black Paint } \\
\text { Gold Paint } \\
\text { Red Paint } \\
\text { Grey Paint }\end{array}$ \\
\hline 3 & $\begin{array}{l}\text { Sumping } \\
\text { Surengpati }\end{array}$ & & & $\begin{array}{c}\text { Leather } \\
\text { Black Paint } \\
\text { Gold Paint } \\
\text { Red Paint } \\
\text { Grey Paint } \\
\end{array}$ \\
\hline 4 & Sumping Waderan & & & $\begin{array}{c}\text { Leather } \\
\text { Black Paint } \\
\text { Gold Paint } \\
\text { Red Paint } \\
\text { Grey Paint }\end{array}$ \\
\hline
\end{tabular}

Figure 10. Sumping (2 Dimensions)

(Used on the Wayang Orang)

(Source : Nugraha, Rika, 2018)

\begin{tabular}{|c|c|c|c|c|}
\hline $\begin{array}{l}\mathrm{N} \\
\mathrm{O}\end{array}$ & Name & $\begin{array}{l}2 \\
\mathrm{D}\end{array}$ & $3 \mathrm{D}$ & Material \\
\hline 1 & Sumping Ricikan & & & $\begin{array}{l}\text { Mixture } \\
\text { Zinc }\end{array}$ \\
\hline 2 & $\begin{array}{l}\text { Sumping Kuda } \\
\text { Lumping }\end{array}$ & & & $\begin{array}{c}\text { Mixture } \\
\text { Leather } \\
\text { Gold Paint } \\
\text { Red Paint } \\
\text { Blue Paint } \\
\text { Green Paint }\end{array}$ \\
\hline 3 & Basic Sumping & & & $\begin{array}{c}\text { Mixture } \\
\text { Leather } \\
\text { Gold Paint }\end{array}$ \\
\hline 4 & $\begin{array}{c}\text { Yogyakarta } \\
\text { Sumping Dance }\end{array}$ & & & $\begin{array}{c}\text { Mixture } \\
\text { Copper } \\
\text { Gems }\end{array}$ \\
\hline 5 & $\begin{array}{c}\text { Yogyakarta } \\
\text { Sumping Dance }\end{array}$ & & & $\begin{array}{c}\text { Mixture } \\
\text { Leather } \\
\text { Yarn }\end{array}$ \\
\hline
\end{tabular}

Figure 10. Sumping (3 Dimensions)

(Used on the traditional dance)

(Source : Nugraha, Rika, 2018)
Joni Permana as one who wrestles in the world of dance culture preservation efforts has great efforts by bringing aesthetics of traditional forms of sumping becoming a very interesting form of sumping. It translates the design through the reconstruction of the material that can be seen from the papers that appear in a show. In addition to in the show, at the hands of sumping from Joni Permana are product designs which have a bricolage (unique), it is very different from the look of sumping in general used as a fashion complement on a dance performance.

Reconstruction of the material through the customization done aims at the preservation of culture with the culture of innovation measures. Customization is done through the use of the material in the form of merging some of the material in the form of cooper processed through techniques of soldering so having a composition design of sumping which has not only aesthetic value, but also a point of interest in any of his work.

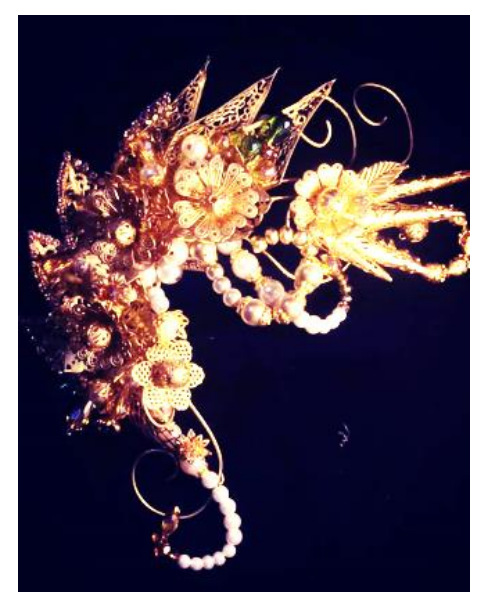

Figure 11. Modification Sumping (3 Dimensions)

Material mixture from cooper and pearl (Source : Permana Joni Documentation, 2017) 


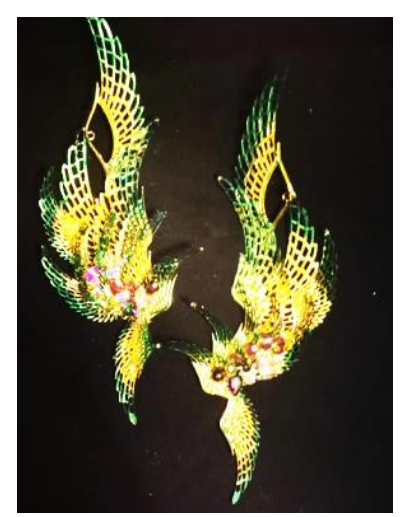

Figure 12. Kujang Pusaka Sumping (3 Dimensions)

Material mixture from cooper and pearl (Source : Permana Joni Documentation, 2017)

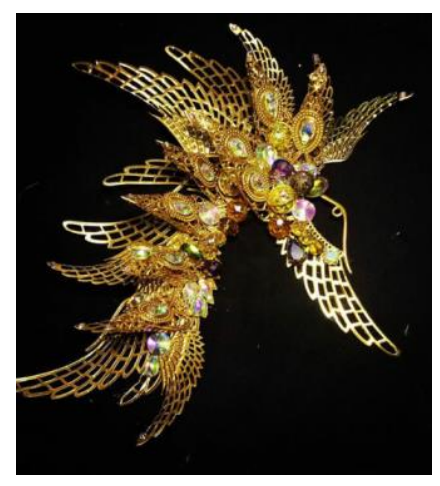

Figure 13. Modification Thailand Sumping (3 Dimensions)

Material mixture from cooper and gems (Source : Permana Joni Documentation, 2017)

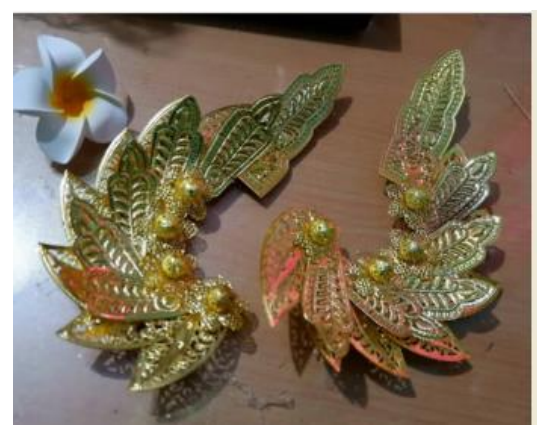

Figure 14. Modification Sumping (3 Dimensions)

Material mixture from cooper and pearl (Source : Permana Joni Documentation, 2017)

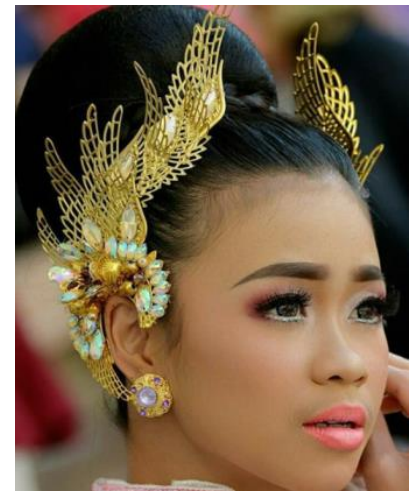

Figure 14. Garuda Sumping (3 Dimensions)

Material mixture from cooper and gems (Source : Permana Joni Documentation, 2018)

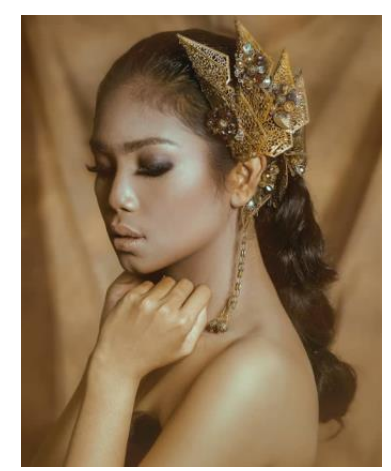

Figure 14. Modification Sumping (3 Dimensions)

Material mixture from cooper and gems (Source : Permana Joni Documentation, 2017)

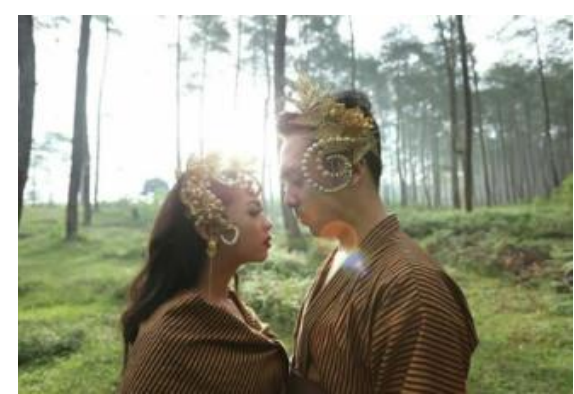

Figure 15. Modification Sumping (3 Dimensions)

Material mixture from cooper, pearl and gems

(Source : Permana Joni Documentation, 2017) 


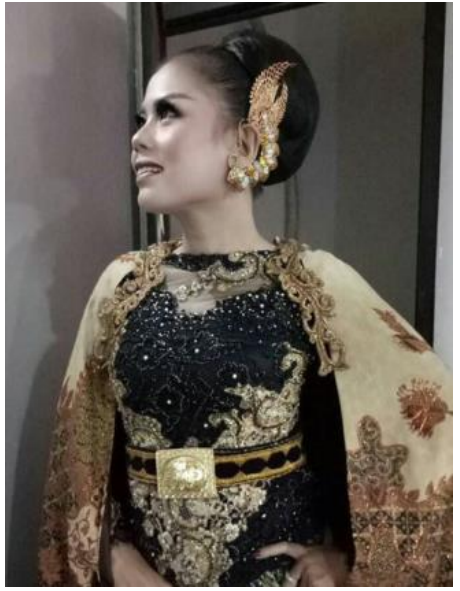

Figure 16. Modification Sumping (3 Dimensions)

Material mixture from cooper, and gems (Source : Permana Joni Documentation, 2017)

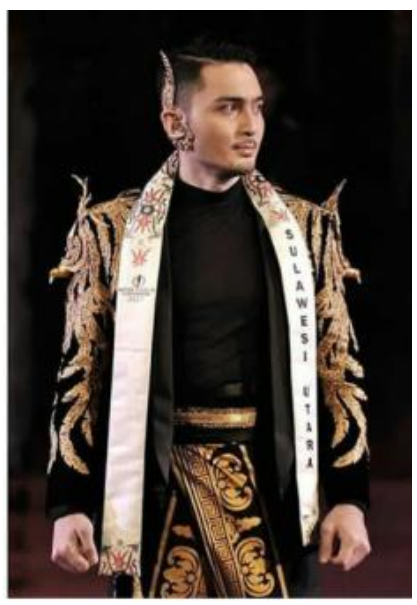

Figure 17. Sawunggaling Sumping For Event Mister Tourism Indonesia (3 Dimensions)

Material mixture from cooper, and gems (Source : Permana Joni Documentation, 2017)

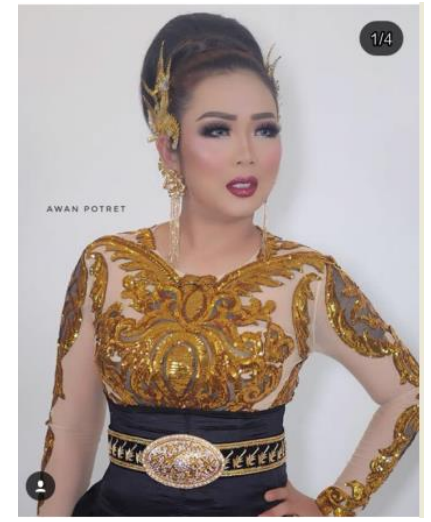

Figure 17. Sumping For Public Figure (3 Dimensions)

Material mixture from cooper, and gems (Source : Permana Joni Documentation, 2018)

The work of Joni Permana is a reconstruction of a material with no form transforming sumping used on the ear. The reconstruction was done as a culture of innovation through the use of a material markedly with the addition of some materials such as pearls, jewels and also a few dominant colors such as the use of gold color on each display sumping.

Full design used on the material in accordance with user needs factors i.e. customize collaboration, where users can discuss products needs to be used. The development of sumping use no longer merely appendages to wear fashion performances yet more shows to the aesthetic values making sumping as a point of interest on the wearer's body.

\section{ADVICE}

The use of sumping is becoming more variable, it should be merged with the addition of material that is more exlcusif such as the use of the materials on any work swarovski display sumping become much more valuable.

\section{THANKYOU}

For Joni Permana to permissions to make design work into material may be useful for all of us 


\section{BIBLIOGRAPHY}

[1] Barnard, Malcom. Fashion Sebagai Komunikasi. Cara Mengkomunikasikan Identitas Sosial, Seksual, Kelas dan Gender. Jalasutra, Yogyakarta.

[2] Burton,Graeme 2012, Media dan Budaya Populer.Jalasutra. Yogyakarta.

[3] Strinati, Dominique, 1995. Popular Culture. Pengantar Menuju Teori Budaya Populer.Ar-Ruzz Media. Yogyakarta.

[4] Laudon, Kenneth.2010.Management Information System. Pearson Education.United States

[5] Rustiyanti, Sri.2012. Menggali Kompleksitas Gerak dan Merajut Ekspresivitas Koreografi.Sunan Ambu Press.STSI Bandung.

[6] Rohendi, Tjejep. 2011.Metodologi Penelitian Seni.Cipta Prima Nusantara.Semarang.

[7] Sachari, Agus.2007. Budaya Visual Indonesia.Erlangga. Jakarta.

[8] "The Four Faces of Mass Customization" Harvard Business Review;1997. Vol 5 Issue 1 Page 91$101 \mathrm{Jan} /$ Feb.United States

[9] Walker,John 1989, Desain Sejarah Budaya, Sebuah Pengantar Komprehensif, Jalasutra. Yogyakarta. 